\title{
Detection of Powdery Mildew Growth in Hazelnut Plant Using PCR
}

\begin{abstract}
Ulku Baykal ${ }^{1, a, *}$
${ }^{I}$ Department of Genetics and Bioengineering, Faculty of Engineering, Giresun University, 28200 Giresun, Turkey *Corresponding author A R T I C L E I N F O A B S T R A C T

Research Article Powdery mildew is a serious disease of economically important hazelnut crop in Turkey. Hazelnut production has been extremely affected by the disease in terms of quality and quantity. The disease is caused by two different fungi, namely Erysiphe corylacearum and Phyllactinia guttata. E. corylacearum has been shown to be the responsible one predominantly for the recent economic damage. The fungi produce a mycelium network on hazelnut plants before they sporulate and visually detected. Early detection of these pathogens is important for management as well as understanding their spread and epidemics. In this study, a PCR assay was developed for the detection of both pathogens from hazelnut plant leaves by targeting their ribosomal DNA genes in their internal transcribed spacer (ITS) regions. Two sets of specific primers were designed for the detection of E. corylacearum and $P$. guttata at an early stage of infection. As a result of PCR, a specific band of $578 \mathrm{bp}$ was observed. The amplicon sequencing confirmed the presence of only $E$. corylacearum, but not $P$. guttata. Therefore, this PCR-based test can identify plants that are infected with powdery mildew before they show any visual signs. From there, the infected plants can be treated or removed before the fungus has a chance to produce spores that infect neighboring plants. These results would help tackle the eradication of powdery mildew.

Keywords: Powdery mildew PCR detection Erysiphe corylacaerum ITS Corylus avellana
\end{abstract}

(iD) https://orcid.org/0000-0003-2441-0592|

This work is licensed under Creative Commons Attribution 4.0 International License

\section{Introduction}

Powdery mildew has become one of the major diseases of hazelnut plants, resulting in a decrease in the yield and quality of hazelnut production. The disease-causing fungi are obligate biotrophs (Takamatsu et al., 2015), that can invade a plant by being invisible for up to two weeks, and then begin to sporulate creating the powdery appearance of a disease symptom. They cannot be cultured and can only survive on living plant tissues. The parasitic fungus exploits its host through a specialized structure, which is called haustorium, by transferring nutrients from plant cells to fungus (Gil and Gay 1977; Hahn and Mendgen 1997; Voegele and Mendgen 2003). Their infection does not cause immediate tissue death. Hazelnuts are susceptible to two types of powdery mildew pathogens: Phyllactania guttada (Hartney et al., 2005; Takamatsu et al., 2008) and Erysiphe corylacaerum (Braun and Cook 2012; Farr and Rossman 2016; Pscheidt and Ocamb 2017). However, the later fungus has been shown to be the predominant cause of hazelnut powdery mildew (Sezer et al., 2017).

Powdery mildew is spread by spores produced on the surface of the infected leaves. The symptoms appear in late spring or early autumn. The mycelia of E. corylacaerum appear on the adaxial side of the leaf, while in P. guttada is on the abaxial side. Conidia are produced throughout the growing season, mainly in mid-spring and early autumn and they are spread by wind or other organisms. They generate white powdery coating on the infected leaf surface. Their existence for the following season depends on the production of asexual and sexual spores. Sexual spores produced in cleistothecia spread in the air and eventually meet their host by the vectors such as winds, insects, and animals. Identification of each fungus can be performed by comparing their fruiting bodies (cleistothecia). Although both produce dark brown spherical cleistothecia, P. guttada and E. corylacearum have distinct appendages: club-like and thread-like respectively.

Spores, the key elements in maintaining the cycle of fungal infection, are produced at the late stage of infection and remain dormant until a suitable healthy tissue is found to infect. Early detection and correct identification of pathogenic fungi can be crucial for early treatment of infection for disease management. PCR assays are an attractive method to detect powdery mildew pathogens because they are fast, sensitive, and accurate in diagnosing powdery mildew disease. 
In this study, PCR-based detection of hazelnut powdery mildew fungi was performed to understand if the infection can be detected at early stages before forming conidiospores. PCR analysis based on the amplification of internal transcribed spacer (ITS) sequences (partial 18S, ITS1, 5.8S, ITS2, and partial 28S) of the powdery mildew fungi (Mori et al., 2000; Cunnington et al., 2003), was done using the infected hazelnut leaves before the symptoms being visible. Early detection of pathogens during the incubation period or at the beginning of the disease would contribute to the rapid prevention and treatment of hazelnut powdery mildew.

\section{Materials and Methods}

\section{Powdery Mildew Pathogen Collection}

The hazelnut plant (Corylus avellana cv Tombul) was used for leaf sampling in a hazelnut field in Giresun (Turkey), in early September 2019. Suckers of hazelnut plants were grown in a growth chamber under a $16 \mathrm{~h} / 8 \mathrm{~h}$ light/dark period at $25^{\circ} \mathrm{C}$ to obtain disease-free leaves as a control. Young leaves with or without lesions were collected and snap-frozen in liquid nitrogen.

Sample Preparation, Genomic DNA Isolation, and PCR Amplification

Leaf samples with or without powdery mildew infection were ground in liquid nitrogen using a mortar and pestle immediately after sampling. Two independent DNA samples were isolated for biological replicates from the leaves collected from the same sucker using the Plant/Fungi DNA Isolation Kit (Norgen Biotek) according to the manufacturer's instructions. DNA quality was checked by running agarose gel. The concentration for each sample was adjusted to $1 \mu \mathrm{g} / \mu \mathrm{l}$. The PCR reaction was performed in a total volume of $50 \mu \mathrm{l}$ containing $1 \mu \mathrm{l}$ of extracted DNA $(1 \mu \mathrm{g} / \mu \mathrm{l}), 5 \mu \mathrm{l}$ of $10 \mathrm{X}$ polymerase chain reaction (PCR) buffer, $1 \mathrm{U}$ Taq polymerase (Invitrogen), 1 $\mu \mathrm{l}$ of $10 \mathrm{mM}$ deoxyribonucleotide triphosphates (dNTPs) (Invitrogen) and $1 \mu \mathrm{l}$ of $10 \mathrm{pM}$ of each primer pair. PCR was performed using the following conditions: initial denaturation $\left(95^{\circ} \mathrm{C}, 3 \mathrm{~min}\right)$, denaturation $\left(94^{\circ} \mathrm{C}, 1 \mathrm{~min}\right)$, annealing $\left(55^{\circ} \mathrm{C}, 1 \mathrm{~min}\right)$, extension $\left(68^{\circ} \mathrm{C}, 1 \mathrm{~min}\right)$, final extension $\left(68^{\circ} \mathrm{C}, 5 \mathrm{~min}\right)$. After 35 cycles, the PCR products were kept at $4^{\circ} \mathrm{C}$ for the agarose gel analysis. PCR products were examined on TAE (Tris-acetic acid-EDTA) buffered $1 \%$ agarose (Invitrogen) gel, stained with ethidium bromide (Sigma) and visualized under ultraviolet light.

\section{Primers Used for PCR}

ITS sequences of $E$. corylacearum were retrieved from GenBank (E. corylacearum GenBank accession number for Turkish isolate: KY082910.1, E. corylacearum GenBank accession number for Swiss isolate: MN822722, P. guttada GenBank accession number: AB080563) and specific primers were designed. The forward primers ECF (5'-CATTACAGAGTGTGAGGCTCACTCG-3'), and PG-F (5'-CTCGTGTGATTGATGAAGTCTGAGC-3') were used in the amplification for E. corylacearum (578 bp) and $P$. guttada (403 bp) ITS regions respectively with a common reverse primer EP-R (5'-CTCGTGT GATTGATGAAGTCTGAGC-3'). The hazelnut Tubulin gene was employed as a plant reference gene. Arabidopsis Tubulin gene TUB2 (GenBank Accession number: NM125664) was used to search for its counterpart from the Corylus avellana cv Tombul whole genome sequence submitted to GenBank (GenBank assembly accession: GCA_901000735.1). The Corylus avellana housekeeping gene Tubulin was amplified (784 bp) with the forward primer CaTUB-F (5'- AAGGAGGCTGAGAACTGTGAC TGTC-3') and the reverse primer CaTUB-R (5'-GTGAT GGGAACACAGAGAATGTAAGC-3') using DNA isolated from the leaves. of hazelnut plant. NCBI Blast search was used to verify the specificity of the primers. Melting temperature (Tm), GC content, and hairpin formation was calculated using Biowire Jellyfish software.

\section{Sequencing}

PCR products were analyzed for the presence of the sequences under question by using the amplicon sequencing of Illiminua sequencing platform. Then, the DNA sequences were put to further analysis by using various Bioinformatics tools including similarity search BLAST, MultAlin, and CLUSTALW for a query DNA sequence.

\section{Results and Discussion}

Corylus avellana cv. Tombul was used as the plant for the detection of powdery mildew fungal growth. It was noticed that this hazelnut variety was the most susceptible variety among the other cultivars found in the orchard. The barely seen disease symptoms were observed as spots and white fungal colonies on adaxial leaf surfaces of the susceptible hazelnut cultivar in an orchard. Mature conidia, which become the source of subsequent infections produced on conidiophores. Microscopic analysis of the infected leaves showed the presence of the fungal conidia on the infected leaves which were visually detectable. (Figure 1).
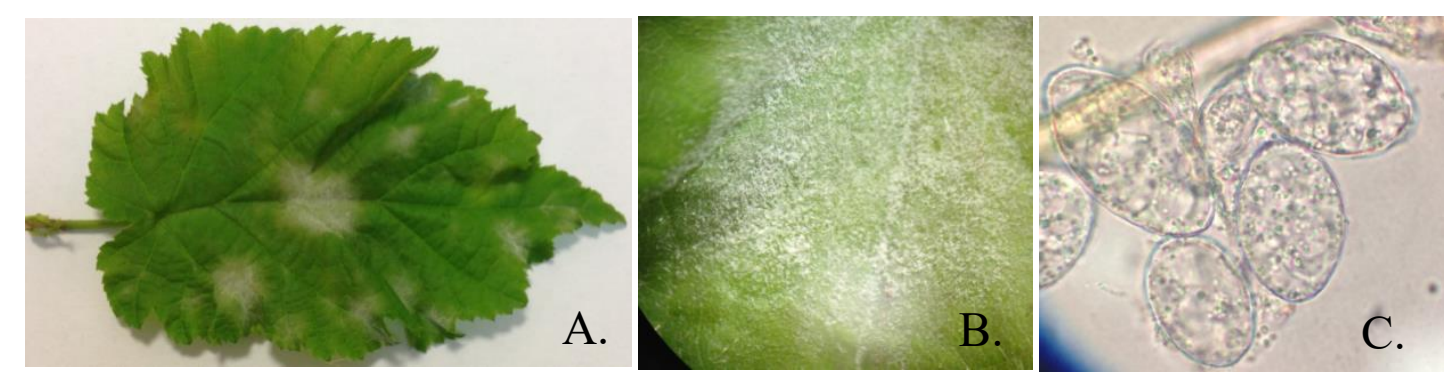

Figure 1. Powdery mildew symptoms on the hazelnut plant (Corylus avellana cv. Tombul) leaf.

A. An infected leaf with many lesions. B. A view of a powdery mildew lesion under a dissection microscope. C. A view of powdery mildew spores from the infected area under a light microscope with $1000 \mathrm{X}$ magnification. 


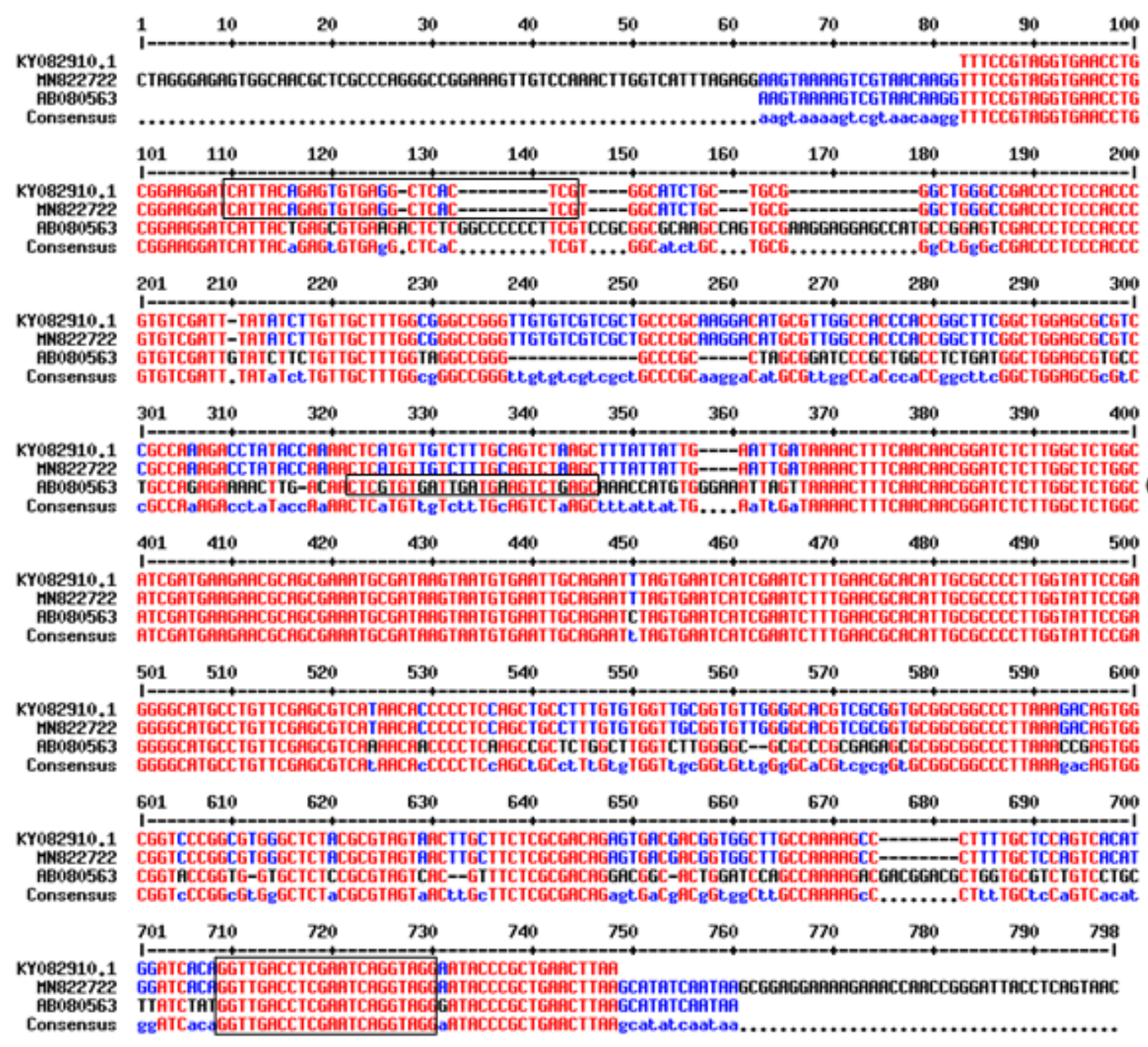

Figure 2. Primer design for the detection of hazelnut powdery mildew pathogens by PCR amplification.

MultAlin alignments of ITS region (18S 3'end-ITS1-5.8S-ITS2-28S 5'end) sequences of E. corylacearum and $P$. guttada were carried out to design the primers. The sequences used as primers were boxed and designated as (I) for a forward primer (EC-F); as (II) for a forward primer (PG-F); as (III) for a common reverse primer (EP-R) and their analysis were performed using Jellyfish software. The primer pairs I and III or primer pairs II and III were used to detect powdery mildew pathogens E. corylacerarum and P. guttada in C. avellana, cv Tombul respectively.

Amplification of certain domains by selecting specific primers and sequencing and surveying the analyses and comparison of sequence results can be used for the fungal detection. Nuclear ribosomal DNA genes are useful targets because multiple copies are present in each genome. Their conserved regions allow to design of broad-range primers and the presence of variable regions is important in the fungal identification (White et al., 1990; Takamatsu and Kano, 2001). ITS region of rDNA is a frequently used barcode for fungal identification. In this study $3^{\prime}$ end of $18 \mathrm{~S}$ rRNA gene internal transcribed spacers (ITS1 and ITS2), the 5.8S rRNA gene, and the 5' end of the 28S rRNA gene were used for developing two sets of PCR primers targeting two hazelnut powdery mildew fungal pathogens: E. corylacerarum and $P$. guttada.

E. corylacearum isolate ASezer's (form Turkey) (Accession No: KY082910.1) ITS region covering small subunit ribosomal RNA gene, partial sequence; ITS1, 5.8S rRNA gene, and ITS2, complete sequence; and large subunit ribosomal RNA gene, the partial sequence was aligned together with that of E. corylacearum voucher
WSS 13507_2 (from Switzerland) (Accession No: MN822722) (Beenken, 2020) and P. guttada sequence (GenBank accession no: AB080563). The sequence alignment was performed to design PCR primers by using MultAlin (Corpet, 1988). The former sequence matched $100 \%$ with the second one (Figure 2). Using this alignment two specific primer pairs, which can amplify ITS regions of each hazelnut powdery mildew fungi was designed.

From a disease control standpoint, early detection of the fungi under question is critical in DNA extracted from plant tissue samples without interference from or interaction with plant DNA. A fungal PCR assay suitable for use with plant leaf tissues was developed to detect hazelnut powdery mildew pathogens. Optimal PCR assay was defined based on its ability to detect two phylogenetically diverse hazelnut powdery mildew fungi and to amplify small quantities of fungal DNA in the presence of a relatively large quantity of plant DNA. The hazelnut suckers from the growth chamber were used to obtain control leaf samples without infection. Leaf samples used for the detection of powdery mildew infection were 
collected from an infected hazelnut garden without pesticides. The samples were prepared in duplicates and the PCR reactions were analyzed on an agarose gel by obtaining a 578 bp PCR fragment (Figure 3). C. avellana cv. Tombul putative Tubulin gene, which was the counterpart of Arabidopsis thaliana TUB2 (Guenin et al., 2009) was mined from GenBank by Blast tool and used as the plant reference gene. The sequence was found in Corylus avellana genome assembly (GenBank assembly accession: GCA_901000735.1), contig: 2739434, whole genome shotgun sequence. The sequence was also searched for the conserved domain in the NCBI website and predicted as the Tubulin beta chain. The PCR reaction produced a $784 \mathrm{bp}$ fragment of this $C$. avellana Tubulin $(\beta$ $T U B$ ) gene (Figure 3 ).

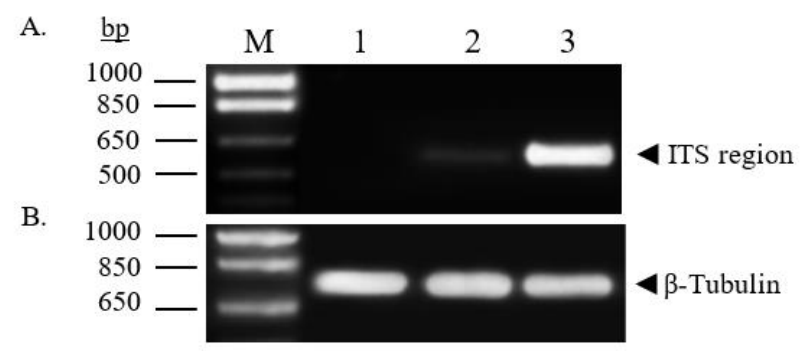

Figure 3. Detection of hazelnut powdery mildew pathogens by PCR.

The sequences amplified from the rDNA ITS region (18S 3'end-ITS15.8S-ITS2-28S 5'end) of E. corylacearum (A.) and $\beta$-Tubulin of $C$. avellana cv Tombul (B.) were analyzed on $1 \%$ Agarose gel. A PCR product of E. corylacearum ITS region was obtained with the primer pair EC-F/EP-R on different DNA extracts from field samples of $C$. avellana cv Tombul leaves with symptoms. The Tubulin gene was amplified as a control. Lane M. 1kb plus DNA ladder, Lane 1 PCR reaction with the genomic DNA prepared from uninfected leaves, Lane

2. PCR reaction with the genomic DNA prepared from the infected

leaves at early stage and Lane 3, PCR reaction with the genomic DNA prepared from the infected leaves with visible symptoms.

Both PCR reaction performed for fungal and plant DNA amplification was used in the amplicon sequencings by Illimuna based platform. The sequencing results of the PCR products demonstrated that only E. corylacearum (578 bp) was present but not P. guttada (403 bp) in the samples. The sequencing results also showed that a primer pair for the $C$. avellana $\beta-T U B$ gene was amplified the predicted DNA region. The DNA sequence analysis proved the presence of $E$. corylecearum so that the method was effective for the detection of the powdery mildew.

\section{Conclusion}

The cultivation of $C$. avellana has become very challenging due to newly emerged disease of powdery mildew. The sequencing results verified PCR-based molecular detection of the powdery mildew fungus, $E$. corylacearum but did not provide any evidence regarding the presence of $P$. guttada in the samples. This study would contribute to future hazelnut crop security by providing better control of the disease before the sporulation of powdery mildew fungi.

\section{Acknowledgement}

This work was supported by the Scientific Research Projects (BAP) Office of Giresun University (FEN-BAPA-230218-04). The author is also grateful to the Giresun University, Construction and Technical Works Office for providing a plant growth chamber.

\section{References}

Beenken L, Brodtbeck T, De Marchi R. 2020. First record of Erysiphe corylacearum on Corylus avellana in Switzerlandand in central Europe. New Disease Reports 41: 11.

Braun U, Cook RTA. 2012. Taxonomic Manual of the Erysiphales (Powdery Mildews). CBS Biodiversity Series 11: 707.

Corpet F. 1988. Multiple sequence alignment with hierarchical clustering. Nucleic Acids Res. 16(22): 10881-10890.

Cunnington JH, Takamatsu S, Lawrie AC, Pascoe IG. 2003. Molecular identification of anamorphic powdery mildews (Erysiphales). Australas. Pl. Pathol. 32: 421-428.

Farr DF, Rossman AY. 2016. Fungal Databases, Systematic Mycology and Microbiology Laboratory, ARS, USDA. http://ntars-gringov/fungaldatabases.

Gil F, Gay JL. 1977. Ultrastructural and physiological properties of the host interfacial components of the haustoria of Erysiphe pisi in vivo and in vitro. Physiological Plant Pathology 10: 1-12.

Guenin S, Mauriat M, Pelloux J, Van Wuytswinkel O, Bellini C, Gutierrez L. 2009. Normalization of qRT-PCR data: the necessity of adopting a systematic, experimental conditionsspecific, validation of references. J. Exp. Bot. 60: 487-493.

Hahn M, Mendgen K. 1997. Characterization of in planta-induced rust genes isolated from a haustorium-specific cDNA library. Molecular Plant-Microbe Interactions 10: 427-437.

Hartney S, Glawe DA, Dugan F, Ammirati J. 2005. First report of powdery mildew on Corylus avellana caused by Phyllactinia guttata in Washington State. Online Plant Health Progress.

Mori Y, Sato Y, Takamatsu S. 2000. Evolutionary analysis of the powdery mildew fungi using nucleotide sequences of the nuclear ribosomal DNA. Mycologia 92: 74-93.

Pscheidt JW, Ocamb CM (Eds.). 2017. Pacific Northwest Plant Disease Management Handbook [online], Corvallis, OR: Oregon State University. http://pnwhandbooks.org/ plantdisease. Accessed 7 September 2017.

Sezer A, Dolar FS, Lucas SJ, Köse Ç, Gümüş E. 2017. First report of the recently introduced, destructive powdery mildew Erysiphe corylacearum on hazelnut in Turkey. Phytoparasitica 45: 577-581.

Takamatsu S, Arakawa H, Shiroya Y, Kiss L, Heluta V. 2015. First comprehensive phylogenetic analysis of the genus Erysiphe (Erysiphales, Erysiphaceae) I. The Microsphaera lineage. Mycologia 107: 475-262489

Takamatsu S, Inagaki M, Niinomi S, Khodaparast SA, Shin HD, Grigaliunaite B, Havrylenko M. 2008. Comprehensive molecular phylogenetic analysis and evolution of the genus Phyllactinia (Ascomycota: Erysiphales) and its allied genera. Mycol Res. 112(Pt 3): 299-315.

Takamatsu S, Kano Y. 2001. PCR primers useful for nucleotide sequencing of rDNA of the powdery mildew fungi. Mycoscience 42: 135-139.

Voegele RT, Mendgen K. 2003. Rust haustoria: Nutrient uptake and beyond, New Phytology 159: 93-100.

White TJ, Bruns TD, Lee S, Taylor J. 1990. Amplification and direct sequencing of fungal ribosomal genes for phylogenetics. In: Innis MA, Gelfand DH, Sninsky JJ and White TJ (eds), PCR Protocols. A guide to methods and applications. Academic Press, San Diego,pp. 315-322. 